\title{
Florestan Fernandes por ele mesmo
}

\author{
BARBARA FREITAG
}

"Ninguém recupera o passado. Contudo, com você crio sempre momentos novos de comoção de mim mesmo. Saio da rotina e voltome para o que há demais profundo $\mathrm{em}$ minha pessoa. Egotismo? Acho que não, porque o 'eu' não entra nisso em nenhuma de suas dimensões limitadoras ou restritivas. É uma liberação..."

Florestan (carta de 29.10.73)

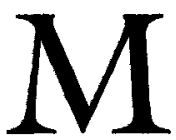

INHA TROCA DE CARTAS COM Florestan Fernandes abrange um período de quase 30 anos. Foi iniciada em junho de 1966 e encerrou-se em setembro de 1994. Selecionei algumas dessas cartas para este número da revista EsTUDOS AVANÇADOS.

Entre os critérios de seleção, dois têm prioridade sobre todos os demais: um de ordem formal; outro, de ordem substancial.

O primeiro refere-se ao espaço disponível na revista para a coleção de ensaios de vários autores, tematizando os mais distintos aspectos da obra de Florestan Fernandes. O segundo, realmente o critério para valer, é fornecido pelo próprio autor das cartas: a sua Selbstdarstellung, a apresentação de Florestan Fernandes por ele mesmo.

Nas cartas selecionadas ele fala de seu percurso acadêmico, político e pessoal, destacando os momentos de produção, de crise e de êxito de seus trabalhos. As cartas vindas de São Paulo, Toronto, New Haven, novamente São Paulo e até de Brasília refletem seus estados de ânimo, suas decepções, suas derrotas e vitórias através de períodos dificeis de formação e deformação da sociedade brasileira: o período da ditadura militar, de distensão e abertura, da redemocratização e dos trabalhos no Congresso Nacional.

Em sua seqüência temporal, as cartas focalizam (com enormes intervalos) as etapas importantes de suas trajetórias profissional e pessoal profundamente entrelaçadas com esses momentos marcantes da história contemporânea brasileira. 
Nas primeiras, o catedrático da USP, no auge de sua carreira, dá orientação a uma estudante alemã em fase de redação de tese de mestrado. Em cartas subseqüentes, Florestan Fernandes faz referência à invasão dos alunos do Mackenzie na Faculdade de Filosofia, Ciências e Letras da USP, da rua Maria Antônia; menciona sua aposentadoria compulsória na USP; comenta suas atividades docentes no Canadá (University of Toronto) e nos Estados Unidos (Yale University); fala da volta (na qualidade de desempregado) ao Brasil, do seu esforço por uma sobrevivência digna, organizando a Coleção dos Grandes Cientistas Sociais na Editora Ática, entre outros assuntos.

O papel de cartas timbrado (ou não) usado para os seus depoimentos, reflete - nos diferentes momentos de sua vida - o vínculo institucional, ou a ausência desse vínculo, demonstrado pelo endereço de sua casa da rua Nebraska $n^{2} 392$, no Brooklyn Paulista (a casa está hoje demolida).

Em quase todas as cartas Florestan faz referência aos textos em que estava trabalhando; às leituras nas quais se encontrava mergulhado; às preocupações e aos fantasmas que o vinham atordoando. Raras vezes sonhava com um futuro melhor para o Brasil, pois analisava implacavelmente os diferentes momentos históricos que the pareciam excluir qualquer devaneio.

O teor das cartas é auto-explicativo, dispensando a caracterização do contexto em que foram escritas. Florestan Fernandes encarrega-se, ele próprio, de situar o leitor no momento histórico, no lugar em que vive, revelando o estado de ânimo no qual se encontra.

Há momentos de desespero e de alegria, de satisfação e descontentamento: "quanto à minha vida aqui, ela é literalmente uma merda" (conforme carta de Toronto a Berlim de 16.10.71). Em outra ocasião confessa (escrevendo de São Paulo a Brasília): "eu me 'desinstitucionalizei' voluntariamente"... "voltei à condição de lumpen, de vagabundo, embora tenha mais dinheiro que em qualquer outra época de minha vida" (conforme carta de 3.5.83). E há relatos da doença que intervém, cada vez mais freqüentemente, bloqueando sua capacidade de trabalho, como deixa claro a última carta mandada de São Paulo a Berlim (29.09.94).

Muitas das cartas selecionadas estão sendo reproduzidas na íntegra. Em algumas, fiz pequenos cortes, ou por serem temas de importância menor (como formas de pagamento de direitos autorais) ou por serem passagens de interesse exclusivamente pessoal e familiar. 
Para ganhar espaço, foram sacrificadas as passagens em que fala um Florestan Fernandes humano, cheio de humor, carinho, compreensão, autocrítica. São as passagens em que - com malícia e ironia fala o meu amigo, "seu velho Florestan", "seu irmão mais velho" ou simplesmente "Florestan", escrito com uma tinta roxa, inconfundível.

O diálogo foi iniciado em junho de 1966, quando estava elaborando minha tese de mestrado, no Departamento de Sociologia do Desenvolvimento da Universidade Livre de Berlim (1). Solicitei, na ocasião, ajuda, conselhos e referências bibliográficas aos três autores estudados na tese.

A correspondência com Florestan Fernandes intensificou-se com a conclusão do trabalho, depois de encontros pessoais em São Paulo (ainda na Maria Antônia) e em Colóquios Teuto-Brasileiros realizados na Alemanha (Universidades de Bielefeld e Berlim).

Florestan Fernandes tornou-se, involuntariamente, o orientador virtual de minha tese de doutoramento (2).

Curiosamente, a correspondência manteve-se até mesmo durante os meus primeiros anos de atividade na Universidade de Brasilia, onde em 1974 havia sido contratada por Maurício Vinhas de Queiroz por recomendação de Florestan Fernandes. Desse período datam as cartas em que sugere minha colaboração na Coleção dos Cientistas Sociais da Ática, resultando no livro número 15: Jürgen Habermas (3).

Na Jornada "Florestan Fernandes", organizada pela Unesp em Marília, final de maio de 1986, Florestan Fernandes encontrou-se com seu passado acadêmico e preparava-se para o seu futuro político.

Foi simultaneamente homenageado por todos os seus ex-alunos, colegas e amigos. Eu estava entre eles. Mas Florestan não gostou da tese que lá defendi, em sua presença, sobre a existência de um "corte" em sua obra, separando o "acadêmico-reformista" do "políticorevolucionário" (4).

Havia entrado no Partido dos Trabalhadores e estava sendo muito cortejado por seus correligionários do PT, pouco antes de sua candidatura e eleição para Deputado Federal.

Foi no momento em que geograficamente estaríamos mais "próximos", morando ambos em Brasília que permanecemos acadêmica e afetivamente mais distantes. Tenho a impressão que o deputado Florestan Fernandes não me perdoou a avaliação de Marília. 
Em seu cartão de Natal (14.12.89) fala, para justificar o silêncio, de uma "recusa aos entes mais queridos", imposta - segundo ele pelo excesso de trabalho na Câmara dos Deputados e pelas muitas viagens. Neste período, as cartas foram substituídas pelos discursos do deputado federal, Florestan Fernandes, proferidos no Congresso, que me eram enviados com regularidade pelo seu chefe de Gabinete.

O dialogo foi retomado e encerrado por Florestan Fernandes, depois de minha vinda para Berlim. Tinha convidado o não mais deputado para escrever um ensaio para o Anuário de Educação - 1994 (5). De início, gostou da idéia (conforme carta de 24.4.94) mas acabou desistindo da elaboração de um texto por razões de saúde.

A correspondência termina assim como havia começado: com Florestan Fernandes em São Paulo e eu em Berlim. Ela exprime uma proximidade intelectual e afetiva ímpar, com as oscilações que a vida impõe a dois amigos vivendo em países e cidades diferentes, com ritmos de vida desencontrados e interesses e convicções nem sempre convergentes.

Por que Florestan Fernandes me escolhera para - em suas palavras - "sair da rotina" e voltar-se para o que "de mais profundo havia em (sua) pessoa"?

Talvez a explicação esteja nos dois traços de minha personalidade que mais o intrigavam: minha nacionalidade alemã e minha origem burguesa.

Minha condição de alemã foi importante, porque a tentativa de Florestan de compreender o Brasil passava por um diálogo polêmico com a cultura européia. Ele precisava de um Outro de quem pudesse se demarcar, afirmando a originalidade do seu pensamento, e de um interlocutor com quem pudesse se comunicar, num horizonte compartilhado de temas e interesses. Fui temporariamente essa alteridade e, graças a ela, essa interlocutora.

Talvez, ao invocar minha condição burguesa, Florestan estivesse, intuitivamente, fazendo apelo à característica central atribuída à mentalidade burguesa, o senso de propriedade. Ele sabia que como boa burguesa, sua amiga guardaria suas cartas como propriedade sui generis, levando-as a toda parte, de Berlim ao Brasil, à Suíça, à Dinamarca, de volta ao Brasil e de novo a Berlim. Florestan Fernandes sabia que esse defeito de classe - $o$ individualismo possessivo - contribuiria para que suas cartas fossem preservadas. E sabia que, burguesa ou não, eu não 
hesitaria em socializar essas cartas no devido momento, pois o autor que vive nelas pertence a todos.

Berlim, no inverno de 1995.

\section{Notas}

1 Em 1965 eu havia proposto ao Departamento de Sociologia como tema de minha tese: $O$ desenvolvimento sócio-econômico brasileiro segundo a perspectiva de trếs cientistas sociais (Gylberto Freire, Florestan Fernandese Celso Furtado). A tese foi orientada pelo professor R. F. Behrendt, catedrático de Sociologia do Desenvolvimento e defendida em julho de 1967. Parte da tese (justamente aquela que discutia a obra de Florestan Fernandes foi publicada por uma pequena editora alemã: Florestan Fernandes: Die sozio-ökonomische Entwicklung aus der Sicht eines brasilianischen Sozialiwissenschftlers (SSIP Verlag, Saabrücken, 1969). Em sua carta de 6.1.70 Florestan expressa sua alegria ao receber um exemplar desse livrinho. Empenhou-se pela publicação da tese, na íntegra, pela Companhia Editora Nacional, depois de ler minha versão traduzida (com a qual não concordava plenamente). Sua perseguição, aposentadoria compulsória e viagem para o exterior (Canadá) inviabilizaram tal projeto.

2 A politica educacional brasileira: agente ou resultante de processos de transformação? foi o tema da tese apresentada e defendida na Universidade Técnica de Berlim em julho de 1972. Foi publicada na Alemanha sob o título Die brasilianische Bildungspolitik: Agens oder Resultante gesellschaftlicher Wandlungsprozesse? (München, Fink-Verlag 1975). Versão reformulada e drasticamente encurtada foi publicada no Brasil sob o título de Escola, Estado e sociedade (São Paulo, Editora Morais, 1985, $6^{\text {a }}$ edição). Assuntos dessa tese são detalhadamente debatidos em uma longa carta vinda de Toronto, de 29.1.71.

3 O livro foi inicialmente projetado pela Companhia Editora Nacional, meados dos anos 70. O projeto foi abandonado por várias razões e retomado, em colaboração com Sérgio Paulo Rouanet, durante nossa estadia em Zurique/Suíça (1976-81), sendo lançado pela Ática em 1980. Há um belo comentário ao nosso texto em uma carta de Florestan Fernandes mandada de São Paulo a Zurique em 5.12.78.

4 Conforme Freitag, B. Democratização, universidade, revolução. Em: Maria Angela D'Incão (org.). O saber militante. Ensaios sobre Florestan Fernandes. Rio de Janeiro, Unesp/Paz e Terra, 1987. Vide também a tese de Eliane Veras Soares: Florestan Fernandes: o militante solitário, São Paulo, Cortez, 1996 [no prelo]. 
5 Este Anuário foi iniciativa de Eduardo Portella, que me encarregou da organização "para não perder os vínculos com o Brasil, durante a estadia em Berlim". Saiu publicado em dezembro de 1994 pela Editora Tempo Brasileiro, Rio de Janeiro, sem uma contribuição de Florestan Fernandes (conforme carta de 29.9.94 justificando essa decisão). Vide também a minha introdução ao Anuário.

Barbara Freitag é professora da Universidade de Berlim, Alemanha. 
De volta de um período de trabalho fora de São Paulo, li ontem a carta que me enviou em 22 de junho. Tive muito prazer ao descobrir seu interesse pelo assunto de que tratou na carta $e$ desejo-lhe muito êxito em sua obra.

Não sei qual é a bibliografia que possui e, dessa, qual é a parte dos meus trabalhos nela contidos. Seria bom se me escrevesse, dizendo o que possui. Durante minha estadia nos Estados Unidos, escrevi um trabalho que interessaria muito, sobre "A dinâmica da mudança sócio-cultural no Brasil". Dele foi publicada em 1965 uma edição mimeografada, em inglês, pela Universidade de Colúmbia (Institute of Latin American Studies). Em português, o traba-lho foi publicado pelos Cadernos Brasileiros ( $\mathrm{n}^{\circ} 35$, maio-junho de 1966), com outro título e com algumas incorreções no texto (é, no entanto, uma edição útil). Para uma reunião sobre ciências sociais, realizada sob o patrocínio de The Social Science Research Council, apresentei um trabalho de interesse para os seus propósitos; e, ainda agora, escrevi um ensaio de $39 \mathrm{p}$. sobre crescimento econômico e instabilidade política no Brasil, para os Colóquios, que se realizarão no próximo mês em Harvard. Se achar interessante, poderei enviar cópias desses trabalhos em português. Basta escrever-me a respeito.

Em função de sua bibliografia, poderei fazer sugestões mais ou menos úteis. Tenho a impressão que, apesar do tópico escolhido, seria bom se lesse trabalhos meus que indicam melhor a minha orientação empírica e os centros de interesses teóricos de minhas investigações. Nos Ensaios de sociologia geral e aplicada, nos Fundamentos empíricos da explicação sociológica e em Etnologia e sociologia no Brasil. O meu livro mais recente (A Integração do negro à sociedade de classes, São Paulo, Ed. Dominus, 1966, 2 v.), contém uma análise bem fundamentada dos problemas de desenvolvimento no Brasil, com vistas para os fatores de arcaização ou arcaizantes que continuam a operar mesmo na cidade de São Paulo. Sobre isso, também escrevi um ensaio "A persistência do passado", que foi apresentado a uma conferência realizada na Dinamarca no ano passado. Gostaria que pelo menos passasse uma vista no meu trabalho de doutoramento ( $A$ função social da guerra na sociedade Tupinambá) 
e no trabalho que publiquei com Bastide (Negros e brancos em São Paulo, cujos capítulos I e II cuidam das relações entre crescimento econômico e mudança social), pois nos pequenos escritos e ensaios nem sempre posso apresentar os fundamentos empiricos e teóricos das idéias que apresento ou defendo.

Quanto a outros autores, se precisar de alguma coisa escrevame. Verei o que posso fazer. Tenho grande admiração por Celso Furtado e acho que ele merece um tratamento carinhoso. Foi vítima de enorme incompreensão e de uma injustiça clamorosa. Ao contrário de Gilberto Freyre, cujo valor seria ocioso ressaltar, ele tem lidado, como eu, com aspectos delicados da modernização da sociedade brasileira. Por isso, caiu vitimado pelo alcance de suas contribuiçṓes - países subdesenvolvidos não possuem um grau de secularização de atitudes suficiente para comportarem obras de investigação objetiva e que contrariam avaliações tradicionalistas, na esfera dos problemas sociais, econômicos e políticos.

Em suma, estou à súa disposição e faço votos para que seu trabalho atinja o seu alvo e contribua para um melhor conhecimento do desenvolvimento das ciências sociais nos últimos anos no Brasil. Como compreendo suas prováveis dificuldades bibliográficas é que me disponho a fornecer indicações que por ventura considere necessárias. Peço-lhe dar minhas recomendações ao Prof. Amora e envio-lhe cordiais saudações.

\section{Florestan Fernandes}

N.B.: Seria bom responder-me com urgência. Penso ir a Massachusetts, no próximo mês, o que acarretará longa demora à resposta de suas próximas indagações. $F F$

Recebi sua carta de 25 de janeiro e agradeço a remessa dos trabalhos do Prof. Behrendt. Certamente, foi muito boa a idéia de mandar-me os trabalhos escritos em inglês. 
Quanto aos dados biográficos, não sei o que dizer. Os dados que já mandei não são suficientes? Seria melhor, no caso de precisar alguma informação, de pedi-las especificamente. Nasci em 22.7.1920; sou casado; tenho 6 filhos e uma neta; quanto aos livros, as teses e os diplomas, já mandei dados a você. Se tiver ocasião (dependendo do trabalho de minha secretária), procurarei atualizar um curriculum meu. Todavia, não posso prometer nada, porque isso exigiria algum tempo e é provável que eu não disponha dele, neste período do ano e com os acontecimentos que estamos enfrentando na esfera da reforma universitária.

A respeito das influências intelectuais, é preciso não esquecer que em. São Paulo iouve uma tríp'ice influência nas ciências sociais (pelos professores que lecionavam aqui): Roger Bastide, Levi Stı auss, Arbousse Bastide, Monbeig, Braudel, Gurvitch, Hugon, Maugué, e tantos outros, acentuaram a influência fran- $\epsilon$ sa na sociologia, na política, na economia e na filosofia (sem contar outros campos da ciência); Herbert Baldus e Emílio Willems representaram a influência alemã na etnologia e na sociologia; Davies, Lowrie e Pierson, com outros professores, representaram a influência norte-americana na sociologia. Colateralmente, algumas influências menores (da missão italiana, da qual o professor Galvani lecionava estatística; e a permanência de Radcliffe-Brown por mais de dois anos). Eu reagi seletivamente a essas influências. Graças aos professores franceses, cuja orientação era eclética e muito "acadêmica", impus-me o dever de conhecer tão profundamente quanto possível as diferentes tendências da sociologia, dos precursores aos modernos e atuais... Graças aos norte-americanos, aprendi as técnicas de investigação empíricas mais exploradas nos Estados Unidos. Graças aos alemães e aos franceses e também por inspiração própria e por causa das leituras que fiz, no campo da filosofia das ciências, valorizei muito a ligação entre teoria e pesquisa empírica sistemática. Por fim, graças à ligação com o marxismo, me interessei deveras pela sistematização teórica da sociologia aplicada, concebendo-a como campo especial da sociologia e compreendendo-a em marcos teóricos que são ainda hoje ignorados nos Estados Unidos (como poderá verificar pelos dois ensaios compreendidos em Ensaios de sociologia geral e aplicada; nesse sentido, fui além de Mannheim, que nunca conseguiu superar o impasse do pensamento liberal, mantendo suas reflexões de ordem prática à margem de qualquer campo fun- 
damental da sociologia). Tinha muitas ambições e pretendia alcançar objetivos demasiado complexos, pelo menos tendo-se em vista a situação de trabalho imperante no Brasil e em São Paulo. Isso tudo me levava a trabalhar arduamente na área da informação teórica; me impunha o dever de enfrentar problemas metodológicos na área da explicação e da integração teórica; e a procurar uma reorganização dos campos da sociologia, com o intuito de valorizá-la como ciência de investigação e de ultrapassar os problemas metodológicos em suspenso.

Acho que consegui algum êxito: nos alvos relacionados com a pesquisa empírica (imprimi o rigor possível à pesquisa da reconstrução histórica, ultrapassando os riscos e as restrições que Radcliffe-Brown levanta a esse tipo de investigação; e pude encadear pesquisa histórica e pesquisa de campo de modo mais amplo e preciso, superando as limitações que aparecem mesmo em grandes obras, como as de Simiand e de Sombart); nos alvos relacionados com a integração do campo teórico (procurando diferenciar os campos, ao contrário do que pretendia Freyer. Assim, pude pôr em evidência os alvos e os problemas lógicos específicos dos diversos modelos de explicação); e quanto à sociologia aplicada, procurando um modelo de explicação que responda aos requisitos empíricos e lógicos da explicação científica, mas segundo propósitos puramente pragmáticos (o que se evidencia nos ensaios mencionados e nos trabalhos sobre educação; não tive, porém, oportunidade prática de participar de programas concretos de intervenção na realidade; a única oportunidade que me ofereceram me levaria a ter de imigrar para a Venezuela e, por isso, tive de recusá-la). No ensino, sempre procurei evitar um dogmatismo prematuro. Sempre preferi orientar os meus estudantes de uma forma ampla, mais informando-os e preparando-os para fazer escolhas, do que escolhendo por eles próprios. Doutro lado, procurei instigá-los a partir das pesquisas, por julgar deformadora a antiga via "filosófica", que dava preeminência ao domínio de ideais gerais, mas esquecia que o cientista se forma trabalhando objetivamente sobre dados de fato, ainda que com propósitos lógicos de explicação da realidade. Por fim, na situação brasileira, tive de dar maior importância a tipos de pesquisa em que o trabalhador isolado ou pequenos grupos de investigadores pode "fazer tudo" - da coleta à organização e à interpretação dos dados. Também consegui êxito no debate dos mesmos que 
poderiam interessar aos leigos e ao grande público (ver Educação e sociedade no Brasil). Mas, aí, surgiram as incompreensões que evidenciam que o grau de secularização da cultura é insuficiente para a comunicação do sociólogo com os leigos letrados.

Além dos autores que mencionou, recebi a influência de vários outros. Da Alemanha, li muito Dilthey, Cassirer, Windelband e Hessen; entre os sociólogos, aproveitei muitas das idéias de Tönnies, de Simmel e de Max Weber. Mas também li outros autores, principalmente Sombart, von Wiese, Openheimer e Thurnwald. Quanto à França, estudei meticulosamente Comte, Durkheim, Simiand, Mauss e Levy-Bruhl. Também li com interesse e aproveitei Halbwachs, Maunier, Bouglé, Davy, Gurvitch, Gaston Richard, Tarde etc., e tanto Le Play como vários dos seus discípulos (Descamps, Roux, Demolins entre outros). Da Inglaterra li e aproveitei o quanto pude de Spencer (e através dele dos organicistas europeus), Stuart Mill, Hobhouse, Ginsperg e Silberman. Da Itália, principalmente Pareto e os estatísticos demográficos. Dos Estados Unidos, li quase todos os autores importantes, de Giddings, Ward, Small, Sumner, Ross, Park, Burgess, Sorokin, Znaniecki, Thomas, Mead, a Parsons, Merton, Levy etc. Seria difícil dizer quais foram as influências principais. Por ordem, de magnitude, poria em primeiro plano e com grandeza análoga Durkheim, Marx e Mannheim. O crivo pelo qual absorvi essas influências, porém, era muito pessoal, o que contribui para explicar porque não consegui levá-las tão longe quanto seria possível. Doutro lado, seria bom ressaltar que sempre valorizei o conhecimento das ciências afins, procurando informar-me quanto ao desenvolvimento da antropologia, da economia, da psicologia social e da política.

Infelizmente, não pude imprimir continuidade aos programas de trabalho que pretendia desenvolver. O meio impôs, por várias vezes, a postergação ou o adiamento indefinido de vários projetos. Muitas leituras, feitas com propósitos mais ou menos ambiciosos, acabaram inexploradas. E, o que transparece da obra realizada ou do ensino desenvolvido, é muito pouco em face daqueles projetos. Mesmo as inspirações teóricas gerais quase não vingaram mesmo entre os discípulos mais ligados à minha pessoa. Minha influência pessoal acabou sendo mais a de um estimulador, que se empenha em criar condições para a pesquisa sociológica e o seu desenvolvimento nas direções potencialmente possíveis da sociedade brasileira. 
Desculpe-me se trato de questões tão delicadas com tanto desembaraço. Como não sei se isso ou aquilo pode ser útil como informação, deixei que a máquina corresse à vontade, ao sabor da memória, mas sem falta de modéstia... Para entender os aspectos da situação cultural, que não posso mencionar e discutir, teria de ler os trabalhos publicados em $A$ sociologia e a etnologia no Brasil e Sociologia numa era de revolução social (é uma comunicação que está por ser publicada pelo Social Science Research Council, sobre as ciências sociais na América Latina).

Se precisar de informações adicionais, peço-lhe para dizer o assunto. Assim se evitará digressões mais ou menos inúteis. Estimo que o seu trabalho continue a progredir, em quantidade e em qualidade, e mando-lhe cordiais saudações,

Florestan Fernandes

N.B.: Desde 1932 e 1933, até hoje, é grande o número de especialistas estrangeiros que trabalham em São Paulo. Depois da guerra, porém, os países que mais tinham missões culturais desistiram das mesmas e menos recursos não permitiram senão soluções modestas. Somente os Estados Unidos queriam manter a área de influência, chocando-se com uma resistência seletiva que nada tem de animosa, mas que é mal compreendida. $F F$

Minha cara Barbara:

S. Paulo, 6.4.67

Gostei muito de sua última carta e fiquei contente com o seu estado de ânimo. Espero que o Prof. Behrendt compreenda o seu esforço e the dê o estímulo necessário. Fazer um trabalho desse a partir da situação cultural alemã é muito difícil. Por maior que seja sua sensibilidade e seu preparo intelectual, o Brasil apresenta-se com uma realidade difícil mesmo para os cientistas sociais brasileiros. Estes, por sua vez, compartilham das ambigüidades e dos dilemas da situação histórico-social que vivem. Não poderia ser diferente. É pena que, estando você tão longe e tendo sabido eu tão tarde de seu trabalho, 
veja-me na contingência de não poder lhe dar uma colaboração mais íntima e criadora.

Não sei se será tão fácil fazer a transição que você pensa de um conceito parcial para um conceito total da "problemática do desenvolvimento". Na verdade, os europeus vêem o desenvolvimento de modo muito diferente, pois criaram a civilização que nos causam os problemas com que nos defrontamos... Apenas, não sei se a questão é puramente de complementar, de se fazer o que Mannheim fez com Kant e Hegel em sua tese sobre a "análise estrutural da epistemologia". Para nós, no plano ideológico a questão é vitalmente política. Herdamos um padrão de civilização graças à "expansão do mundo ocidental moderno": quer dizer, graças à colonização e ao capitalismo comercial... Em seguida, os principais momentos do nosso desenvolvimento relaciona-se com o destino dessa civilização. Em um trabalho, que está quase pronto, sobre "A revolução burguesa em processo", e que lamento que você não tenha lido, assinalo esse fato. Com a emancipação política e com o capitalismo industrial, assumimos novas posições de dependência em face dos países e das economias "metropolitanos", revertendo, cada vez de forma diversa, à condição estrutural que Weber designaria, apropriadamente, como de heteronomia total. Assim, os povos que nos deram um começo demográfico "branco" e o seu padrão de civilização, nos retiram, literalmente, qualquer autonomia. Se o Brasil quiser ser independente, precisará imitar a Alemanha do último quartel do século xIx: realizar sua integração nacional. Para isso, terá de romper não as barreiras do subdesenvolvimento, mas os laços de dependência que impedem qualquer evolução autônoma do País. Nesse ponto, lamento dizer-lhe com tamanha franqueza, a posição da Alemanha não é diferente da dos Estados Unidos e outros países que nos "ajudam". Dirigem o seu "auxílio" no sentido de aumentar sua hegemonia, a qual definem e realizam com muita eficácia de maneiras indiretas e diretas. Eis aí a questão. Nós não temos uma ideologia própria e para vermos o nosso destino de maneira independente, somos forçados a fazer uma revolução copernicana na ideologia transplantada, criada para os centros hegemônicos, não para as sociedades nacionais subdesenvolvidas e dependentes.

Quanto à questão das ambigüidades e contradições do meu 
trabalho: acredito que são inevitáveis. Procurei formar-me com o rigor possível. Nem sempre, porém, consegui superar as limitações a que me referi. Todavia, não tentei fórmular a idéia de que exista uma "sociedade planificada" no Brasil. Defendi, ao contrário, idéias no sentido de que a planificação se faz necessária e urgente. Mesmo nações ricas e desenvolvidas se vêm forçadas a apelar para a planificação, para corrigir desvantagens ou manter suas posições na estrutura mundial de poder. O Brasil, com maior razão, precisa do planejamento para combater a fome, a miséria e o atraso cultural. Agora, é difícil dizerse como chegar ao planejamento. Aquilo que eu chamo de horizonte cultural médio e a própria tradição cultural do País criam obstáculos de superação muito difícil. Os cientistas sociais, pelo menos os melhores, avançaram o bastante para vencerem as limitações da velha tradição acadêmica. Acabaram como eu e Celso Furtado: ele com os direitos políticos cassados e eu preso e tendo de bater nas portas da justiça para defender a liberdade de pensamento e a dignidade intelectual do investigador. Dessa perspectiva, o nosso avanço em direção ao "planejamento democrático" tem de ser forçosamente "teórico" e "político". Para nós, a questão de "educar o planejador" existe; mas, ela é uma manifestação romântica. Seria preciso educar a sociedade para ver no planejamento uma técnica social necessária e útil - ensinar a compreendê-la, a usá-la e a respeitá-la (não empregá-la como um meio para aumentar o poder autocrático das camadas conservadoras, irracionalmente colocadas diante da mudança social como se dèsejassem ser os últimos coveiros - dos seus próprios interesses ou valores sociais e do Brasil como nação). A sociedade ainda não formou, não utiliza nem é sensível a uma "consciência racional da situação" nem tão pouco evolui numa direção lídima e substancialmente democrática. Como escrevi no ensaio sobre "A comunicação entre o sociólogo e o grande público", ele preenche - com outros cientistas sociais - o papel de um fator de agitação e de antecipação, uma espécie de guarda avançada da "consciência nacional". Se tivermos sorte e a sociedade brasileira conseguir superar seus dilemas, então o planejamento se converterá numa realidade e, no processo, a questão da educação dos planejadores será naturalmente desenvolvida...

Gostaria muito que viesse a São Paulo, em outubro, como supõe que será possível. Já gosto de você e vê-la será para mim uma 
fonte de prazer. Poderemos, assim, conversar sobre o seu trabalho e quem sabe se conseguirei ser melhor interlocutor que correspondente! Queria, muito, que você lesse o trabalho que estou escrevendo como resposta intelectual mais completa ao drama brasileiro. Infelizmente o ensaio que deveria ter 80 ou 120 p. já ultrapassou esse limite que o editor me impôs (para publicar "A revolução burguesa em processo" com outros trabalhos). É o primeiro trabalho no qual realizo uma exploração mais intensa de conceitos e procedimentos interpretativos de M. Weber (não por motivos conservadores, ao contrário) e acredito que consegui estabelecer uma ponte harmoniosa entre Weber, Mannheim e Marx, na explicação de processos históricosociais seculares. Se você se prontificar a lê-lo, assim que terminar a redação e conte com uma cópia, mandarei para você. Agora, que está livre da tese, poderá fazer uma crítica mais cerrada das minhas idéias.

Com um abraço muito cordial,

Florestan Fernandes

N.B.: Desculpe-me: não tive tempo, fiquei para fazer revisão da carta!

Sua carta chegou em um bom momento. Pude apreciá-la no que ela tinha de melhor: deixou-me muito contente. Infelizmente, a minha vida anda numa barafunda. Não é tanto desorganizada; eu é que não tenho mais controle do tempo. Muitas conferências, como dizem os estudantes - para "conscientizar" e lá vai o meu tempo. Como se trata de uma forma de luta, acedi. Mas pus um limite: fiz a última conferência no último domingo (aliás, duas). Este mês, irei a Porto Alegre, mas em compromisso especial. Fiquei devendo aos estudantes e professores de lá essa demonstração de reconhecimento e de solídariedade. Foram os únicos, sob a vigência dos atos institucionais do governo Castelo Branco, que me convidaram e toparam a parada. Depois de tomado o cinema em que deveria falar, ia falar no parque, 
quando arranjaram outro local. Assim, eles tinham um crédito e vou lá fora de qualquer programa, fazer três conferências na semana que corre.

A nossa escola foi bombardeada: pelos "alunos" do Mackenzie, ou melhor, pelo cCC (comando de caça comunista). Em um dia, o conflito foi localizado; no dia seguinte, os jovens da extrema direita atacaram rijo, com a polícia espiando e apoiando como se a faculdade fosse um parque de tiro ao alvo. Destruíram tanta coisa, de cortar o coração. Fiquei furioso. Mas, nada pude fazer - nem posso nem poderei. $O$ remédio não está em responder ódio com ódio. Mas, em corrigir a sociedade brasileira. $\mathrm{O}$ que é difícil. Para mim, a violência é um recurso político: só deve ser utilizada para atingir certos fins quando não existem outros meios e existem probabilidades de mudança da situação. A luta atual está entre o meio fascismo (o fascismo disfarçado existente) e o fascismo declarado, que a extrema direita quer impor ao País. É difícil ter êxito político em tal contexto, principalmente porque a violência faz parte da opressão organizada, manipulada a partir de cima pelas classes no poder.

Estou preparando um novo livro de ensaios. Reúne algumas conferências (as que considerei melhores) que pronunciei no decorrer da campanha que fiz em prol da reforma universitária que deverá ser também uma reconstrução da sociedade: r.u. quer dizer, para nós, construção de uma sociedade democrática) (1). Ia mandar o meu livro sobre "Sociedades de classes e subdesenvolvimento" para você, aproveitando a ida do Prof. Rosenthal. Todavia, com os acontecimentos imprevistos, não nos encontramos mais e eu fico the devendo o livro. Ele fez muito sucesso. Quase sem nenhuma propaganda, a edição está prestes a esgotar.

Envio-lhe um caloroso abraço,

Florestan Fernandes

Nota

1 Que eu viria a comentar em minha contribuição para a Jornada de Marília (Unesp). $B F$ 
Desculpe-me o atraso com que respondo à carta que me remeteu, juntamente com o manuscrito. Acontece que fiquei doente - tenho propensão à hipertensão e a complicações cardíacas - e o material que me remeteu chegou numa época em que estava sob repouso absoluto, por ordem do médico. Quando mudei de status, subindo para o de doente em repouso relativo, andei vistoriando a correspondência e vendo uma coisa ou outra. Aí já estávamos em janeiro.

Ainda assim, li todo o trabalho (1). Acho que the fazem falta a leitura dos trabalhos que Celso e eu publicamos ao tempo em que você escrevia o seu livro e logo depois. Quanto a mim, fiquei surpreso com o diagnóstico: não pertenço apenas teoricamente mas também praticamente à esquerda. Só não participo de um partido, porque não existe; e por formação universitária, só poderia ser um marxista na tradição européia, isto é, democrática e heterodoxa. Acho que se você tivesse todos os meus escritos (o que seria difícil: comecei a escrever em 1942) e se tivesse tempo de ler melhor a obra dos três autores veria que a localização não está totalmente correta. Celso desempenhou papéis políticos, mas como "técnico": ainda hoje quer resguardar a sua liberdade, como cientista e como homem de ação, mantendo uma neutralidade calculada diante das opções com que nos defrontamos. Só aceita uma definição, implícita nos seus trabalhos: a preferència por um capitalismo de Estado, que seria uma via para enfrentar os dilemas de um País subdesenvolvido.

No entanto, digo essas coisas sem me queixar. Porque coloquei em primeiro plano a soluçio dos problemas, nunca me manifestei, de modo sistemático, como "socialista"; preferi fazê-lo numa posição que acarreta os seus equvocos: a do "sociólogo participante". empenhado nos processos de democratização das estruturas sociais, economicas e poltticas do seu Pias. Apenas não entendi porque não percebeu e nà pòs em eridència a ènfase que sempre dei ao processo de altonomi/acáa da sociedade brasileira (2). Esse aspecto e essencial para apreender minha posição diante do desenv olvimento. tanto teorica quanto praticamente. E aparece em escritos mais ou menos antigos: alguns reunidos em livros no "Nudanças sociais no Brasil"; $\mathrm{e}$ 
outros em "Ensaio de sociologia" e "Sociologia numa era de revolução social”.

Encaminhei o seu manuscrito à Companhia Editora Nacional (Zahar Editores, que seriam mais fáceis, não quiseram arriscarse com o livro; nesta ocasião: CF e FF são assuntos explosivos). Mas, não sei ainda qual será o resultado. Se for negativo, tentarei outras soluções.

Envio-lhe votos de Feliz 1969 e abraços muito saudosos,

Florestan Fernandes

Notas

1 Tradução para o português de minha tese de mestrado completa conforme nota 1 de minha introdução. $B F$

2 Diante dos USA e da Europa! BF

Desculpe-me ter esperado até hoje para responder à sua carta de 16 de março. É que aguardava uma resposta da editora e eles nunca resolvem! A esperança é que o Sr. Octales, proprietário da Companhia Editora Nacional, apoie a publicação. A Editora da Universidade de São Paulo recusou-se a ajudar, este ano, a edição de qualquer livro de sociologia... O seu estava no grupo. Como o Sr. Octales pode demorar, açhei melhor escrever-lhe.

As coisas andam mal. De um lado, não me restabeleci completamente. A alta não foi dada e deverei ir na próxima terça-feira fazer novos exames. Mas, o médico deu plena liberdade para o meu trabalho... De outro lado, eu e outros professores da USP (e de outras escolas) fomos aposentados compulsoriamente pelo Governo Federal. Trata-se de uma medida que esperava desde 20 de dezembro do ano passado. Os seus resultados nefastos: perda súbita de parte substancial da renda; necessidade de acumular alguns trabalhos remunerados de natureza intelectual; 
premência de sair do Brasil (pois o artigo $3^{\circ}$ do ato institucional $\mathrm{n}^{\circ} 10$ fecha-nos as portas do ensino, da pesquisa e da tecnologia, ao alvitre das autoridades). Como estava prevenido, havia aceito um convite para lecionar em Toronto, de setembro em diante. Depois, chegou outro convite de Harvard, que coloquei na época subseqüente. Agora, vieram mais convites, mas não posso aceitá-los, pois gostaria no futuro de acumular alguma experiência em instituições internacionais, que façam pesquisa e cuidem da aplicação dos conhecimentos. Não sei se isso será possível. Mas, pretendo tentá-lo... Ainda é tempo de aprender algo novo em áreas que são atraentes.

Não se preocupe comigo. Saberei me arranjar, pois tenho vivido dias piores. Também não dê importâncias às minhas críticas. As vezes as pessoas se julgam de um modo e são vistas de forma diferente pelos demais. Quem teria razão? Conheço as minhas intenções. Talvez não as formule tão claramente quanto seria necessário. Ou quem sabe o que eu considero importante seja secundário. $O$ apreço que tenho por você e seu trabalho pode ser medido pelo esforço que fiz e continuo a fazer para vê-lo publicado em português. Lembre-se de mim como estivemos juntos, numa cantina de Berlim, tomando vinho. Acho que lá estava menos chato e pretensioso...

Aceite as minhas saudações mais cordiais,

Florestan Fernandes

Minha querida Barbara:

Toronto, 6.1 .70

Você não pode imaginar a emoção que senti ao ver o seu livro (1), quando retornei ao Brasil. Cheguei dia 4, mas somente dia 5 vim ao meu escritório e examinei a correspondência. Já fiquei sentido com uma coisa: parte do seu ingente esforço não foi aproveitado, já que somente a parte que tratava de mim é que veio a lume.

Não lhe escondo que, para mim, a sua obra é importante. Ela me dá uma sensação nova. Embora não seja mais vaidoso que 
os outros, encontro no seu trabalho um duplo suporte - intelectual e moral. Penso que a publicação é oportuna e que ajudará a causa dos "cassados" no Brasil.

Vou escrever ao Dr. Diether Breitenbach para saber se posso comprar uns cinco exemplares, para enviar à minha família e a alguns amigos no Brasil. É uma idéia tola, mas inocente. Acredito que vão gostar do acontecimento e, quiçá, isso ajude o editor brasileiro a resolver de uma vez se publica seu livro em conjunto.

Só agora me dou conta do seu prejuízo. Praticamente, você trabalhou de graça - 15 exemplares, sem compensações financeiras. É uma crueldade.

Em abril irei à Alemanha, de corrida, porque é época de exames, aqui. Gostaria de vê-la, nem que fosse por alguns minutos. Não sei se lhe contei na carta que lhe escrevi. Trata-se de uma reunião sobre questões raciais, em Bielefeld. Escreverei em tempo para você.

Muito obrigado por tudo. E, no mínimo, até abril. Com um saudoso abraço,

Florestan

Nota

1 Florestan Fernandes. Die sozio-ökonomische Entwicklung Brasiliens aus der Sicht eines brasilianischen. $B B$

Querida Barbara,

Toronto, 22.4.70

Foi uma alegria ser recebido em Toronto por sua carta. Conheci logo a letra e o envelope. Foi uma recepção muito agradável, embora eu ache que você exagera a meu respeito. $O$ homem é limitado por sua condição humana. Não vou mais longe que os outros e talvez tenha certas limitações incuráveis, que nascem de cicatrizes do passado. São as cicatrizes que me tornam um tanto relutante para aproveitar as vantagens que minha posição me proporciona (como o caso da dotação oferecida pela Funda- 
ção Volkswagen, com a qual vou fazer o mesmo que já fiz com ofertas análogas da Fundação Ford), e que percebo me levam a agir de forma irracional. Um paradoxo. Tentar ser "racional" por vias irracionais. $O$ que fala, porém, é o meu passado, tão vivọ em minha consciência crítica, de criança que começou a enfrentar a vida em toda a plenitude com pouco mais de seis anos. Mas, se não me livro do meu passado, não posso ser mais que uma aberração no mundo em que vivemos, no qual as criaturas se "valorizam" através do mercado (como diria o circunspecto Max Weber) e trocam o hoje pelo amanhã e o amanhã pelo depois do amanhã. A fonte de minha força não passa, portanto, de uma imensa fraqueza, já que estou condenado a ser um mero intelectual.

Ao chegar, também recebi carta do Thomaz Aquino de Queiroz. Muito amiga e delicada. Mas, foram-se por água abaixo as perspectivas de um emprego na Cia. Editora Nacional. Ele me aconselhou a não me "amarrar" aqui, mas a pensar em permanecer fora do Brasil mais dois ou três anos. Assim, não tenho como trabalhar fora da sociologia em meu país, pois aquela seria a única empresa que, se possível, me daria um emprego (no qual, eu suponho, seria capaz de me sair tão bem quanto qualquer outro colega).

$\mathrm{O}$ círculo se fecha. Vim para cá pensando em um ano. Andei considerando convites para passar tempo. Porém, agora vejo que tenho de mudar meus planos. A Myrian, numa carta que me enviou, e que também estava à minha espera, fala que poderá vir morar comigo. Respondi aceitando mas que conversaremos em São Paulo. A vida é dura demais para ela e a família precisa mais dela que eu. Enfim, resolveremos isso como for melhor!... (...)

Voltei muito cansado, mas tive de retomar a rotina, ler vários papers e preparar o terreno para a próxima semana, na qual vou fazer uma tournée desastrosa (com várias conferências em três universidades tão diferentes como Rutgers, Princeton e Yale). Será que vou agüentar?

Agradeço-lhe de novo por seu carinho,

Florestan 
Sua carta veio em bom momento, Recebi-a há alguns dias. Numa fase em que ando no fundo do poço - cansado do meu trabalho, cansado de ser professor e até cansado da comida, da cidade e do tipo de vida que levo em Toronto. Acho que atingi o limite da saturação.

Ainda por cima, as notícias que vêm do Brasil sempre ajudam a afundar o poço. A morte de meu querido amigo Baldus, as dificuldades que minha mãe enfrenta para fazer duas operações urgentes (a idade exige um tratamento difícil e vai postergando as operações), pequenas questões de família, e o brutal panorama político, que você demonstrou conhecer tão bem em sua carta. Para terminar tudo vem a notícia, em carta de Heloisa (minha filha mais velha), de que a polícia foi duas vezes à minha casa para me prender. Não é cabo de esquadra? De emprego que é bom nem ouço falar. Minhas cartas, por enquanto (há quase 3 meses) estão aguardando resposta. Como diz o ditado brasileiro: em tempo de murici, cada um cuida de si.

Continuo com ânimo. Enquanto se vive, se luta ou então não se entrega a rapadura. (Acho que estou em verve folclórica, pois repeti outro provérbio). Todavia, torna-se cada veź mais difícil para mim estabelecer uma ponte entre o que sou e o que faço e o que desejaria ser e fazer. Não tenho pena do Florestan, velho e calejado; mas às vezes olho para mim mesmo com certa ironia, pois me especializei em dar murros em ponta de faca e agora que me vejo lançado realmente no mercado, como mercadoria estimada em dólares, sinto que as minhas técnicas estão superadas e que seria melhor vender sorvetes numa rua quente de São Paulo do que ser professor de sociologia no Norte das Américas. (...)

No meu estado de espírito, não me atrevo a escrever sobre o Canadá. Um dia falaremos, o que é melhor. Quanto ao desejo de voltar ao Brasil, já nem é mais coragem. É parte de uma mecânica, em que a vida obriga e em que o eu cede. Quero muito voltar. Mas, mesmo que não o quisesse, teria de fazê-lo. Vamos ver se as chamadas "condições externas" não cortam essa necessidade, ao mesmo tempo objetiva e subjetiva, pela essência dialética. 
Com um abraço carinhoso,

Florestan

Barbara, minha querida,

Toronto, 29.1.71

\section{(...)}

Na sua carta existem três coisas distintas. Uma, que vem a ser uma crítica da simulação da sociologia (que parece ser o equivalente de certo tipo de situações, em que se tentam sem crivo "espírito experimental"). Pareceu-me pasmoso o que descreveu. Para mim, um professor de sociologia só pode ser ingênuo e cínico por caviloso e consciente oportunismo. É o que parece ter acontecido. A "ciência" está injetando na Europa a mesma dose de pusilanimidade, de co-optation e de conformismo deliberado (embora também bem disfarçado) que já instilou nos Estados Unidos. Hoje, aprende-se mais lendo um bom artigo de orientação crítica - quando os jornalistas fazem uma descrição "honesta" - ou um romance, do que se lendo obras de cientistas políticos, sociólogos e economistas de "alto nível". Fico cada vez mais revoltado com esse "alto nível", os "modelos" sofisticados e o vazio total que eles envolvem; uma ciência útil para quem comanda burocraticamente e pode pagar um "preço funcional" pelas decisões impostas de cima para baixo. No fim de tudo, a curto prazo, no preço está incluído o custo histórico da correção da própria história. No entanto, a largo prazo, o que estão pagando e comprando é a própria ruína. A história também é "funcional" e possui mecanismos de correção que não podem ser pagos e comprados. Confunde-me esta estupidez, que cega os agentes humanos até para os seus interesses mais profundos. E entristece-me o fato de europeus com latino-americanos, asiáticos e africanos no coro - empenharem-se na mesma via de adoração de uma ciência que pode ignorar fatores que não são essenciais (ou podem ser controlados parcialmente) pela superpotência hegemônica, que pode 
desprezar pelo menos a história imediata, que cerca a dominação mais completa e total do homem e da sociedade satelitizados.

O outro ponto é a sua crítica à idéia do Estado-educador. Se você me perdoa, você tomou a nuvem por Juno... De fato, o que você leu são trabalhos de polêmica e propaganda políticas. Eu estava engajado numa merda de uma política pequeno-burguesa, na qual os pressupostos do jogo político consistiam em nossa fraqueza. Um punhado de intelectuais, de estudantes, de líderes sindicais e políticos de esquerda, tentando enfrentar a avalanche da fome católica pelo controle das consciências e dos setores conservadores pela destruição da escola pública independente. Naquela situação, recorri a um equivalente da simulação: os pressupostos ideais do Estado democrático. Uma maneira de fazer a "crítica moral", que desarma os inimigos e cria aliados, por ser irretorquível. Funda-se nos dados e nas exigências do "sistema". Se ele existe, logo tem de manter-se e de aperfeiçoar-se. Nesse quadro, no qual imergia como uma putaine respectuese e com dor de cornos (tendo de falar ao público reiteradamente - o que às vezes não consta dos escritos - que aquilo não correspondia aos valores de minha posição pessoal, socialista), o argumento era por essência político e visava fazer aliados. O que consegui (e outros junto comigo). Uma boa parte dos "liberais" de várias gamas saíram do convento e se puseram na liça (inclusive os atuais arautos da Revolução, educadores como Laerte Ramos de Carvalho, Roque Spencer Maciel de Barros, Carlos Correia Mascaro e tantos outros). Portanto, tenho direito de pedir uma moratória e uma nova leitura. Eu não criei a sociedade brasileira como cla é. Quem estava usando a idéia do Estado democrático educador não era o sociólogo, mas o ativista empenhado numa campinha, que usava a razão como podia e o ponto de vista sociológico como uma dimensão do pensamento crítico. Nunca me passou pela cabeça conceber a nossa sociedade como uma sociedade que tenha tido um Estado educador; e basta ler o que escrevi (em livros como Mudanças sociais no Brasil, $A$ sociologia numa era de revolução social; um dos ensaios contidos em Ensaios de sociologia geral e aplicada e no livro que os milicos não deixaram sair, $A$ universidade brasileira: reforma ou revolução) para se perceber que eu sempre compreendi o Estado como uma ditadura de classe (no bom sentido e na melhor 
tradição marxista e revolucionária). Aliás, o ensaio que escrevi sobre as ditaduras militares também deixa patente o meu pensamento claro, embora o inglês esteja construído a la portuguesa...

$O$ terceiro ponto é o mais importante. $O$ seu projeto de trabalho. O meu comportamento habitual, nesses casos, sempre foi o de tomar conhecimento e de esperar o rebento final, para depois manifestar-me. Há um impulso criador dentro de cada um de nós. Quando uma pessoa elabora um projeto de trabalho, responde a esse impulso criador, que é preciso estimular. No seu estado intelectual, porém, não posso proteger-me sob esse escudo (que usei com todos os meus assistentes e com amigos como o Antonio Candido ou o Schaden). Acho o plano um pouco ambicioso. Não sei quantos documentos ou dados você pode coligir aí. Mas mesmo no Brasil seria difícil - com a limitação de tempo que pesa sobre a sua tese - desenvolver tal programa. Contudo, ele tem a vantagem do alargamento horizontal da perspectiva. Você pode colocar em perspectiva diferentes desenvolvimentos, em seqüência ou concomitantes, que marcam a evolução recente do sistema educacional brasileiro. Duas críticas me parecem óbvias. Uma, a seriação que você propôs é mais externa que inerente aos dinamismos dos processos educacionais, considerados sociologicamente (baseia-se na seriação dos governos). Ora, apesar de caráter inovador das contribuições dos pioneiros da "educação nova", a política educacional brasileira - mesmo quando sob a influência direta do Darcy e do Anísio (considere como eles ampararam a acomodação do governo de Goulart às exigências conservadorasclericais, quando da aprovação da lei de diretrizes e bases, o que denuncio num dos artigos coligidos em meu livro, sem mencioná-los - são amigos queridos e agiram movidos por circunstâncias que talvez os tenham convencido que era melhor uma "adaptação funcional" que um conflito sem fim) - nunca saiu da órbita da "reprodução da ordem existente". No "manifesto", que foi redigido por Fernando de Azevedo, e em algumas reformas feitas em escala estadual (Distrito Federal, Bahia, São Paulo etc.) às vezes chegaram a tentar a solução burguesa da "revolução dentro da ordem". Fernando chega a insinuar explicitamente, em um dos trabalhos, que seria preciso fazer a revolução antes que o povo a fizesse nas ruas. Mas uma burguesia dependente só conhece a contra-revolução... Se não pode 
manter o poder por bem, fá-lo pelos meios possíveis... Daí a constante conservadora da evolução da sociedade e, por conseguinte, da educação. A outra crítica é mais complexa. Você pensa (em função do que presumi do título) pôr em evidência as funções construtivas da "política educacional" no Brasil (eis as suas palavras: “... sua contribuição para o desenvolvimento global da sociedade brasileira"). Na verdade, a situação é menos brilhante. Sempre tivemos alguns educadores e alguns grupos pensando "prá frente". Doutro lado, porém, os "donos do poder" sempre conseguiram cortar as asas desses agentes históricos frustrando os seus propósitos. Em conseqüência, a sociedade avançou além e por cima do sistema e da política educacionais. A sociedade - por causa de fermentos incontroláveis, como a expansão demográfica, o ritmo de crescimento das cidades, o desbordamento das barreiras sociais etc. teve um ritmo histórico mais intenso que o da política educacional. Os educadores não querem perceber isso, porque eles contam a história como agentes de uma "revolução educacional" (ou de várias) que não houve (ou não ocorreram). É amargo dizer isso. Mas é a verdade. A política educacional representa um ponto de equilíbrio político estático que impóe, de cima para baixo, uma conspiração contra a educação e contra a influência aceleradora da educação na revolução nacional brasileira. Esse é um ponto delicado, difícil de abordar, mas o mais importante de todos. Como as elites culturais de uma burguesia impotente acabam agindo contra os alvos e os valores do seu próprio pensamento político e forjando políticas educacionais irmanadas com o processo de preservação do status quo, do subdesenvolvimento e da satelitização permanente, inclusive no campo da educação. Falo-lhe com a franqueza de quem andou pelas ruas, pelas salas ou pelos auditórios mais diversos com a bandeira oposta, de arrebentar os diques para que a própria sociedade liberasse a educação como processo social e impusesse uma política nacional de educação, capaz de servir de fulcro para a eliminação dos privilégios educacionais e para a supressão da dependência quase-colonial em relação ao exterior. No fim, o controle caiu na mão da Superpotência Hegemônica, com as comissões mistas MEC-USAID! $\mathrm{E}$ os privilégios educacionais permanecem intactos.

Barbara, não leve a mal a digressão. Não quero dar aulas. Mas fiquei tão emocionado, que desandei. É um diálogo à distância, 
espremido pela falta de tempo. Espero que você o enfrente $e$ rejeite, ou se ajuste a um barco que está sob bombardeio constante... mas que não naufragou.

Um abraço carinhoso,

Florestan

Barbara, queridinha:

Toronto, 16.10 .71

(...)

Recebi o seu cartão da Bolívia (1) e reagi a todos os acontecimentos como uma história fantasmagórica e funesta. Tinha informações sobre a Bolívia de um amigo brasileiro do $\mathrm{PCB}$, que naturalmente fazia um retrato bem diferente do que resulta de sua carta. Eis aí algo para meditar e sofrer. A América Latina não faz suas revoluções: o que pensa agora do meu trabalhinho, que você leu? Estamos numa encruzilhada e o que nos falta é a dimensão humana do processo revolucionário, a partir de baixo...

Quanto ao senhor Wolf Grabendorff: será que pode se comunicar com ele. $O$ trabalhinho que ele pretende está encampado pelo Dr. Graebener. Aliás, já saiu publicado em inglês (por iniciativa talvez do Prof. Bastide: saiu no Journal des Américanistes, o que quer dizer - não será visto nem cheirado...). Se o Dr. Graebener concordar, não tenho objeções na publicação. O que não posso é escrever um trabalho sobre o assunto agora. No entanto, eu preferiria que ele publicasse Patterns of external domination in Latin America, para cuja edição não é preciso autorização alguma. Ele pode indicar a edição original e pronto! Pode entender-se com ele? É mais rápido e eficiente.

\section{(...)}

Quanto à minha vida aqui, ela é literamente uma merda. A cidade de Toronto é ótima; só tenho recebido atenções e favores; e deveria ser mais reconhecido. Mas não me encontro mais 
com a minha profissão e detesto a condição de expatriado por simulação. Sei muito bem que ando por uma trilha irracional. Porém, quem é que disse que devemos ser sistematicamente "racionais"?! Doutro lado, minha experiência me ensinou que vou trocar uma merda por outra. Como pôr-me em paz comigo mesmo numa situação em que terei de engulir a própria consciência para sobreviver? Sentirei, a cada hora que viver, o apodrecimento moral da pessoa, a corrupção indireta e envolvente das pequenas concessões e dos sacrifícios invisíveis. Mas, o que fazer? Posso mudar a história para fazer "escolhas racionais"? Portanto, vou-me lançando para a frente, com a disposição de que "o que for soará".

\section{(...)}

Com todo o carinho e os votos de que a alegria de viver brote de novo, saindo de dentro de você e com toda a exuberância,

Florestan

Nota

1 Golpe militar na Bolívia em que Banzer derruba Torres com quatro aviões da Força Aérea boliviana. Nosso hotel - eu estava em La Paz dando assessoria a Projetos de Desenvolvimento do Governo Alemão - foi atingido pelas balas de metralhadoras. $B F$

A sua carta encheu de sol a minha sala de trabalho e de alegria o meu pobre viver de homem solitário. Não respondi de imediato, porque tinha muitos assuntos andando e queria colocá-los corretamente na carta-resposta.

\section{(...)}

Até agora, os livros que Graebener me mandou não chegaram aqui, e com tanto trabalho pela frente, a ser feito de modo rápido, extenuante e nervoso, sinto-me vazio e irritado. Como vou terminar o ano letivo dez dias antes que os outros, estou 
num corre-corre danado, para conseguir dos estudantes os papers em tempo de ler e avaliar, e de terminar os três cursos que me cabiam (que ficaram "marretados"!).

Dia 9 de dezembro embarcarei para o México. Depois da conclusão do seminário sobre "Classes Sociais na A.L.", deverei embarcar para o Brasil dia 19 (aliás, ainda lá não vou cumprir o programa, pois dia 19 é o dia de encerramento do seminário, ao qual não estarei presente!). Parece que me tornarei conhecido como o figurinha difícil, que faz o possível e impossível para complicar a vida dos outros. Já imaginou como os meus programas fora da rotina devem atrapalhar meio mundo?!

Por fim, desligo-me de vez de Toronto. Preparo um grande jantar em um restaurante chinês para quase 30 amigos (outros irei tratar em pequenos almoços, que saem mais baratos e demonstram a mesma intenção), com o carinho da gratidão. Por sua vez, ando às voltas com jantares e pelo menos duas festas-jantares com que serei ritualmente excluído desta simpática sociedade da América do Norte.

Espero que agora tudo esteja mais assentado para e em você. Não sei como vai o seu trabalho mas penso que corre de vento em popa, pois você não é de abater-se a ponto de destruir o equilíbrio moral da pessoa. Agora, que me vou daqui, gostaria de dizer-lhe que suas cartas foram um elo entre uma solidão relativa e uma esperança ardente. Quantas vezes elas me ajudaram a enfrentar as duras realidades da vida de bom ânimo? Sou-lhe grato por isso. Desejo-lihe um ano de 1972 cheio de felicidade.

Florestan

Querida Barbara, S. Paulo, 8.3.73

Que bom que você sente alguma "necessidade" de escrever-me. Ponho-me em contato com você, por pouco que seja. As novidades, sobre a sua situação e decisões, sobre a UnB, o Flávio e o Maurício são boas de ouvir, embora em algumas coisas a minha 
perversidade natural preferisse uma história às avessas.

Terminei a introdução do Livro de Leituras sobre o Lenine. Não fiz tudo o que queria - em vez de $150 \mathrm{p}$. de texto, gostaria de espaço para 450; em vez de 30 p. de introdução, gostaria de ter umas 50 ou 60. Mas, o que fazer? Dentro dessas limitações, dei conta do recado da melhor forma que me foi possível.

Toquei-me para o litoral depois do casamento da Bia. Fiquei uma semana no Guarujá e 9 dias em Itanhaém. Depois, fui a Três Lagoas, visitar a Sílvia. Sou um pai em circularidade... e em circulação.

Escrevi um pequeno artigo para Opinião, com o título "Democracia e desenvolvimentò", com o intuito de mostrar que, em 1962, já havia condenado a fórmula corrente. O que fiz, de fato, foi analisar o contraste entre a revolução burguesa nos países de capitalismo avançado e nos países de capitalismo dependente e subdesenvolvido, pondo ênfase nos efeitos políticos. $O$ Brasil entrava só como ilustração. Contudo, o artigo foi vetado. Querem que escreva outro. Mas, sobre o que? Ou sou muito burro, ou não sei ajeitar-me ao espaço político que me resta.

Retomei, no Guarujá e em Itanhaém, o trabalho sobre revolução burguesa no Brasil. Redigira um largo capítulo, em 1966 (o qual então passei a máquina); e tinha uma parte de outro capítulo sobre a emergência da ordem social competitiva. Todavia, $o$ assunto não me atrai tanto, em nossos dias. Bati à máquina o que escrevera sobre o elemento competitivo na antiga ordem escravocrata e senhorial - mas não vou terminar o capítulo. Vou deixar como está, largando às urtigas a análise de como a ordem social competitiva emergiu historicamente. Quem precisa saber isso, em nossos pobres dias? Em compensação, vou escrever um capítulo novo, sobre as características da hegemonia burguesa no período da intensificação da industrialização. Junto os três capítulos, publicando o livro desse jeito (e não de acordo com o plano inicial, que era mais extenso e complexo. Penso que é o bastante, pois a revolução burguesa "já foi”...

Fico por aqui, enviando-lhe o meu enternecido carinho.

Que seria de carinho sem amor?

Florestan 
(...) A sua carta perdeu atualidade, depois do nosso encontro aqui em casa. Relendo-a, vejo que as suas indicações pessoais ultrapassaram todos os assuntos. Menos um. A sua pergunta a respeito do que ando escrevendo. Não estou escrevendo nada e também não sinto vontade de escrever. Depois de escrever tanto, ando de maré baixa e não sei quando retomarei o antigo entusiasmo. Leio muito, mas sem método, como se fosse um adolescente desorientado. Também, falta-me um objetivo central. Os livros correm-me pelas mãos e, aqui ou ali, fixo-me em um, e leio-o de cabo a rabo. Um dia, deu-me na telha escrevinhar umas notas sob o título "Sociologia e Socialismo", como artigo para Opinião. Ele foi publicado (só trocaram o título). A outra ocupação é descobrir o que acham do último livro. Os comentários verbais têm sido decepcionadores; e o que sai em jornais ou revistas vai pelo mesmo teor. De alguns, esperava crítica mais profunda; de outros, pelo menos uma resenha bem feita. Ocorre-me pensar que já não existe uma "boa" cultural geral. Poucos leram os clássicos do socialismo e, entre esses, acho que ninguém possui treino sociológico. É uma pena. Até Trotsky, o mais radical dos socialistas revolucionários, sabia que a revolução burguesa não constitui um "episódio histórico" e que ela se atrasa (aliás, sua "lei do desenvolvimento desigual e ampliado" poderia ser aplicada ao tema fora do contexto russo). Por aqui, parece que pensam que já não existe burguesia e que a dominação que nos sujeita é puramente astral. Tão pouco entendem que o processo descrito teria de ocorrer de modo muito diverso. A burguesia que retarda ou que não completa a revolução nacional precisa, naturalmente, usar o Estado Nacional para se fortalecer e se privilegiar. Mas o que fazer? Preciso munir-me de muita paciência para suportar, ao lado da marginalização, uma incompreensão generalizada.

Não pense que esteja triste. As reflexões são tão objetivas quanto as anotações de um curso ou de um livro. A vida é assim mesmo e só as pessoas muito medíocres vêem suas perspectivas realizadas. É que eu gostaria de ser útil e vejo que o esforço está longe do alvo.

Um carinhoso abraço para você e o Sérgio, 
Não avalie o meu contentamento pelo tempo que demoro em me fazer presente; foi uma imensa alegria para mim a notícia de que tudo correu bem e, mais ainda, que você e o Sérgio foram premiados com a Adriana. Sabe que é o nome da neta que, atualmente, é mais chegada a mim e vive mais comigo que com qualquer outra pessoa?

Parabéns a você e ao Sérgio: e muitas felicidades para a Adriana.

A razão da demora da resposta: andei um pouco fora dos trilhos e, como sucede comigo, lendo e escrevendo à la neurótico... Como tinha de redigir um pequeno trabalho para livros em homenagem a Wagley e a Bastide (neste caso: um segundo livro, pois já contribuíra para outro anteriormente, com "Os aspectos políticos do dilema racial brasileiro"), redigi um artigo sobre "Vinte e cinco anos depois" (uma análise do negro no momento atual, depois de um quarto de século da nossa pesquisa). Não é viver demais? Além disso, escrevi um pequeno ensaio sobre " $\mathrm{A}$ sociedade escravista no Brasil", que devo apresentar como paper em uma conferência (seria melhor dizer simpósio) sobre as economias de plantação no Novo Mundo. Há tempo tinha vontade de escrever algo a respeito. Precisaria de umas 120 ou 150 p.; mas deixei tudo por 50 (o dobro do que permitiam). Mas deu para fazer uma concisa análise sobre o modo de produção escravista, que eu acho que estava faltando; e para ter, assim, o que se poderia chamar de a base material para explicar a estrutura, o funcionamento e a evolução da ordem escravocrata e senhorial. De um golpe, repus os problemas das relações entre escravidão e capitalismo no Brasil - apanhando como um modo de produção precapitalista, inserido no circuito do capital mercantil, a largo prazo pôde tornar-se um fator de acumulação originária, o elemento em que se funda o clímax da sociedade estamental e de castas e o pião do giro pelo qual se deu a traição à revolução republicana, convertida pelos antigos fazendeiros numa forma de continuar o mandonismo e o antigo regime. Em suma, o seu velho Florestan, que nem sempre você entendeu bem na análise que fez da minha obra.

Quanto a novidades, pedi passaporte para dar um giro pelo norte das Américas: Toronto, New Haven, Austin (onde vão realizar um colóquio sobre $A$ Revolução Burguesa no Brasil, em 
três seções que tomarão todo um dia e a noite), Gainesville, New York etc... Vou correr a casa de alguns amigos - talvez um adeus ou, quem sabe, um novo começo? Estou um pouco saturado de tudo isto e de uma luta sem fim que não conduz a nada, como se eu fosse uma reedição empobrecida do herói mais quixotesco da pobre cena histórica latino-americana e brasileira. Nem me resta dizer: fiz o que pude. $O$ que se deve fazer depois disso? Não pense que se trata de pessimismo. Acho que transcendi aos quadros de uma atuação que foi devorada pela condição periférica do intelectual brasileiro. A sociologia crítica pode servir para a pose de alguns felizardos europeus e norte-americanos. Para nós ela não é nem o sucedâneo de um envelope de cafeaspirina... Mas a história tem os seus ritmos e a sua direção; pior para os lúcidos ou para os honestos ou para os inquietos e pior ainda para os que são tudo isso de uma vez.

Nada deve empanar, porém, o motivo desta carta. Meus parabéns a você e ao Sérgio e que a Adriana consiga viver em uma sociedade socialista, porque não acho que alguém possa ter "paz e amor" ou felicidade no sentido autêntico da palavra dentro do mundo criado pela "civilização industrial capitalista".

Com um beijo para você e um abraço carinhoso para o Sérgio,

Florestan

Agradeço muito a sua carta. E fiquei contente com ela. Afinal, vocês já estão se virando, como dizemos em nossa gíria. Há muito que fazer na Europa e com o tempo você acabará conquistando a posição a que tem direito. Só que é preciso ter paciência. Você caiu do céu, para eles; e, se for bastante hábil, poderá afirmar-se não só no plano teórico como também como especialista do Brasil (com possibilidades de estender aos poucos sua especialização para outros países da América Latina). É um saber que não deve ser negligenciado. De qualquer modo, enquanto espera a hora da consagração é bom explorar (no 
sentido estético e geográfico) o ambiente e aproveitar os seus recursos intelectuais. Acho tudo muito bom. E com o Sérgio ao seu lado, você tem tudo do que precisa para vencer. Nada de "lamúrias" ao estilo alemão. Você tem de afirmar-se à moda brasileira, sem o "vim, vi e venci", mas com aquela arrogância ingênua que é típica da mentalidade brasileira, a qual nos é muito favorável no contato com povos ou muito arranjadinhos (pelos padrões convencionais) ou muito tímidos. Isto não implica qualquer forma de cinismo. Um modo de ser é um modo de ser. Agindo a brasileira você abre mais as portas que aceitando a formalidade suíça-alemã.

Quanto à minha vinda para cá, foi decidida ao acaso, no fim de novembro. Recebi o convite pelo telefone e, depois, ele foi confirmado por carta. Estou aqui desde 9 de janeiro e devo voltar entre fins de maio e começos de junho. Recebi um convite para assinar um contrato com a Universidade de Yale, por três anos. Eles só têm dinheiro para pagar-me um semestre (ou para contratar um professor jovem por todo o ano). São as vantagens da velhice... Escrevi para casa, para sondar as reações da família. Contudo, antes que elas se definissem, eu próprio chegara à minha decisão. Resolvi não aceitar. Acho que devo tentar a minha vida lá, como ela tem sido possível. Ao ler a segunda parte de A sociologia no Brasil, que já está circulando (recebi um exemplar aqui) verá que não tenho liberdade para agir de outra forma. Não posso dizer uma coisa e fazer outra. Seria muito fácil - o que não está no meu gênero. Além do mais, acho que o meu ciclo institucional está encerrado. Poderei fazer algo aqui ou ali, mas retomar o trabalho acadêmico intensivo e cerrado não me atrai mais. $O$ rato que escapuliu da ratoeira não volta a ela, mesmo que seja atraído pelo melhor queijo do mundo. Imagine um homem. Por que deveria?

Comigo vai tudo bem. A saúde foi testada por um check-up mastodôntico! Só o problema crônico da hipertensão. Também umas pontinhas de saudade da terra e da minha gente. E a horrível sensação de que perdemos a batalha, apesar de termos pelo menos alguns entre nós - feito o possível para vencê-la. Isso, contudo, importa pouco. A guerra continua. Enquanto existir capitalismo nada pode impedir essa realidade. Se não tivemos um 1905 pelo menos aprendemos um pouco mais sobre os circuitos que se fecham em nossa história e que, para abri-los, não basta a dinâmica intrínseca à sociedade de classes, 
que somente reproduz sua ordem econômica, social e política. Pergunte ao mestre Sérgio se não é verdade... Como diplomata versado em Gramsci, ele sabe que o desmoronamento do capitalismo pode tomar vários rumos, mesmo os mais imprevistos. Não vivo só de esperanças. Contudo, para manter uma opção em planos tão abstratos sob compromissos tão tensos, é necessária uma forte dose de esperança.

Agradeço a sua carta. Envio um abraço carinhoso para você e o Sérgio, com lembranças para o Prof. Steger,

Florestan

Quanto ao seu livro (1), seria melhor enviá-lo para a minha casa. Não acha?

Nota

1 Escola, Estado e sociedade ( $1^{2}$ ed. São Paulo, Edart, 1977). BF

Ótimo receber tantas notícias boas, sobre você, a Adriana e o Sérgio. Ao que parece, vocês acertaram os ponteiros com o ritmo europeu, o que não é difícil... Encanta-me especialmente que o Sérgio colabore com você na tradução! (1) A editora acertará com você os detalhes (o pagamento máximo que conseguimos foi de $\operatorname{Cr} \$ 60,00$ por página). $O$ que vale mais, porém, é o prazer do trabalho feito.

Eu quase não tenho novidades. A mesma vida. As conferências aqui e ali com a vivacidade e o calor humano de sempre. $O$ que é um intelectual de vanguarda? Nós não temos "vanguarda", de modo que ataco como posso e tento segurar as pontas... Apoio mesmo só de um ralo grupinho de inocentes. Parece que os inocentes irão salvar o mundo, aqui e aí. 
Também dei um curso de extensão cultural no Instituto Sedes Sapientiae (e, última das novidades), comecei a lecionar na PUC, tentando pôr em prática a linha de trabalho que recomendo em "Sociologia como Contestação" (agora cap. 7 em A Sociologia no Brasil, já esgotado). Poderia parecer que deveria ficar contente. Não fiquei. A minha reação é melancolia. Perdida a identidade profissional, o ensino não traz aquelas compensações tão maravilhosas. Gosto do contato com os jovens e eles ainda me consideram parte da grei. Todavia, já sou pão amanhecido. Há quem goste. Contudo, eu próprio não tenho ilusões. $O$ meu momento já passou. Faço o que posso, à maneira artesanal, com consciência do "dever" e do "melhor possível". A magia, porém, se quebrou há tempo e eu contento-me com esse desdobramento do artesão que sempre viveu dentro de mim.

Sinto muita falta do velho ambiente. Trabalhava-se, lutava-se, discutia-se, vivia-se. Hoje, como na política, o clima é de desencanto. Não perdi a tempera, mas sinto-me como se combatesse moinhos de vento, sem ser um Quixote... A sociologia, por sua vez, resvalou e o socialismo continua sempre muito difícil. Eu próprio, ao que parece, compliquei o meu caminho e tenho de renascer das cinzas... ou levar a breca! No ínterim, a volta às salas de aula tem a importância de ocupar-me física e mentalmente, saturando um vazio que quase me destruiu.

Eis aí. Um pouco de melancolia para temperar a trepidação dos "ares da Europa". Com um abraço carinhoso para você e o Sérgio,

Florestan

Nota

1 Dos textos de Habermas para a Coletânea Ática. BF 
Espero que você e o Sérgio, com os filhos, estejam todos muito bem. E gostaria de saber se Sérgio parou nas 560 p. ou foi além: se a obra é importante, como você diz, não faz diferença o volume. Aliás, eu não posso criticar ninguém, pois andei perpetrando teses de "larga envergadura". Só desejo, de todo coração, que ele alcance muito êxito.

A sua enumeração de atividades é soberba. E você, que dizia que não encontrava trabalho e o que fazer... Parabéns!

Quanto a mim, andei pelo hospital das Clínicas (22 de julho em diante), cheguei a ficar em estado de coma por algumas horas, mas já estou bem. Na semana passada tirei duas radiografias dos pulmões e os resultados deixaram os médicos muito contentes. Ainda enfrento algumas seqüelas. Porém, parece que tenho parte com o diabo...

(...) Consegui abrir minha coleção sobre "Pensamento socialista" com $O$ que Fazer? de Lenin, para a qual fiz uma apresentação curta mas que está sendo muito apreciada. Além disso, saiu o meu livrinho sobre Lenin, pela Ática, e foi um estouro editorial. A edição já está se esgotando, em menos de dois meses! A Hucitec republicou a minha entrevista para Trans/Form/ Ação como livro (com o título $A$ condição de sociólogo, pois repeli o título original da revista, muito pretensioso: sobre o trabalho teórico...), e lançou uma reorganização de velhos ensaios com o título $O$ Folclore em questão. Fora isso, tive $3^{\text {a }}$ reedições de $A$ Integração e de Fundamentos (aliás, esta obra teve várias reim- pressões, que não contaram). Portanto, o ausente está presente, como sempre. Também dei algumas conferências, antes da doença e já nesta semana; e, no primeiro semestre, dei o curso sobre "A sociologia numa época de crise de civilização", para alunos pós-graduandos da PUC. É tudo! lamentavelmente, já não gosto de dar aulas. É um sacrifício, que tenho de aceitar. Quanto à PUC nela me sinto um estranho. E não deveria sentir-me?

Um abraço muito carinhoso para você e o Sérgio. Do quase defunto,

Florestan 
Espero que tudo esteja bem com você, o Sérgio e os filhos. No cartão, você não menciona a carta que lhe eścrevi. Mas, ela deve estar com você!

Só recebi o seu trabalho no fim da tarde de sexta-feira. No sábado, não pude devotar-me à sua leitura. O que fiz no domingo. Você e o Sérgio fizeram um trabalho excelente. Não tenho reparo algum a fazer e já recomendei a publicação integral, acrescentando que se deveria dar prioridade à edição por causa do seu caráter especial (para aproveitar a originalidade dos textos).

Escaparam alguns lapsos que corrigi. Nada que exigisse consulta! Quanto à substância da contribuição, ela está acima do nível médio que recomendamos aos organizadores. Trata-se de texto destinado ao trabalho didático e você sabe, por experiência direta, que não somos lá essa coisa. O estudante - e quiçás também o professor - precisam de algo mais ou menos acessível. No entanto, a linha da coleção é não interferir na qualidade intrínseca (ou no "padrão de trabalho") dos projetos editoriais da coleção que dirijo: assim temos maior flexibilidade e podemos forçar, aos poucos, uma elevação para cima do teto cultural. O que significa que vocês colaboraram comigo mais do que pensam.

Além dos méritos da introdução, que realmente apresenta Habermas e vai dos ensaios ao seu pensamento profundo (e vice-versa), me impressionou o prefácio dele. Nunca li algo tão humano: e que faz refletir, porque mostra o judeu defendendo uma tradição acadêmica que foi lançada fora pelos alemães! Uma barreira ao envolvimento norte-americano e ao "barbarismo" correspondente. Ele luta, a um tempo, por legitimidade e por hegemonia intelectual, defendendo implicitamente uma identidade intelectual que não é "judia" (ou "israelita". ou "sionista") mas arraigadamente alemã.

Quero aproveitar a oportunidade para fazer mais duas coisas. Uma, agradecer a colaboração que deram e perguntar-lhes se não querem embarcar em outro autor (podem sugerir; em seguida, digo se está ou não "tomado"...). Outra, desejar-lhe um 1979 muito feliz. Este ano foi pesado, para todos. Vocês tiveram 
um quinhão de dificuldades. Faço votos que o próximo ano seja cálido e cheio de promessas.

Com um abraço carinhoso,

Florestan

Nota

1 Coleção Grandes Cientistas Sociais (Coordenador Florestan Fernandes) Jürgen Habermas, $n^{\circ} 15$, Editora Ática, 1980 (Organizadores Barbara Freitag e Sergio Paulo Rouanet).

Desculpe-me. Mas tenho tido tanto trabalho que não me foi possível culdar da correspondência (tenho o mau hábito de juntar as cartas para responder de uma assentada; tomei a sua, desta vez, porque só iria responder na semana que vem!).

Como vão, você e o Sérgio: refeitos da imersão na barbárie? (1). Ele deve estar mais lépido, livre do abacaxi da tese e muito contente com a figura que fez! E você? Nunca pensei que fosse tão maternal. Pelo que parece, você é mãe com os filhos e mãe e meia para com o Sérgio!... Devo-lhes de novo os parabéns e gostaria de mandar o meu recado ao Sérgio: ao defender a tese ele não botou banca, mas se comportou como quem está por cima. Gostei de ver.

Recebi cartas suas (a de agosto inclusive com cópia via Carolina) e um cartão. Você quer elogio do "pai". Mas quem sou eu para elogiar gente famosa? Sinto-me cada vez mais distante da "academia" (por que academia?) e a sociologia já foi! Gostaria de uma boa revolução socialista, dessas que não deixam espaço para qualquer social democracia à germânica. Isso sim. Então, sou um herege. Levo bafo de onça para o seu puritanismo sociológico. Fora isso, você sabe que só aprendi a elogiar você, para que você passe da condição maternal para a do gênio compreendido. 
Vejo que você continua a progredir e que já conquistou o seu espaço na universidade alemã. Para ser franco, não sei se devo ficar contente. Sem qualquer pessimismo e também sem qualquer frustração ligada à idade - sinto que recebi mais do que devia e talvez mais do que merecia - o trabalho acadêmico me deixa cada vez mais furioso e mesmo a coleção "Os Grandes Cientistas Sociais" eu mandaria às favas se não tivesse responsabilidade diante da Editora Ática. Todavia, você lutou muito e começa agora a colher os frutos. No começo, eles chegam devagar. No futuro, verá, você nem terá tempo ou lugar para acolher tudo que irão querer de você. A vida é assim...

A solução dada ao livro de Habermas foi excelente. Aliás, você e o Sérgio são autores formidáveis. Gostaria de ter pelo menos mais uns dez como vocês. Não precisaria mais! Meus parabéns, de novo.

Quanto ao Basil Bernstein: fiquei indeciso. Tenho na verdade dois pedidos para incluir lingüistas na coleção. Sugeri à editora a inclusão da Lingưística; eles não querem. Ele teria de entrar, portanto, na sociologia. Pode programar um livro nas bases que você conhece e mandar-me a relação dos textos? Se puder simplificar a questão dos direitos autorais, tanto melhor. Se não puder, a editora resolve (com demora: o problema está no exterior, não aqui!).

Com um abraço carinhoso para você e o Sérgio,

Florestan

Nota

1 Sergio e eu passamos com Adriana dois meses no Brasil por ocasião da defesa de tese de doutorado de Sérgio na usp (Teoria crítica e psicanálise), aprovada com 10 pela Banca. Orientadora Ruth Cardoso. Membros da Banca: Francisco Weffort, Gabriel Cohn e Guilherme de Albuquerque... Florestan esteve presente na defesa e na festa depois da defesa. $B F$ 
É bom que você e o Sérgio estejam de volta. Brasília pode não ser o melhor lugar do mundo. Mas, você conquistou um lugar dentro dela e a unB deve a você uma reparação, que terá de vir, hoje ou amanhã. Para o Sérgio, de outro lado, as perspectivas maiores estão aí mesmo. Há que ter paciência... e garra!

Ao receber sua primeira carta falei com a Carmen e ela se mostrou interessada em você. Todavia, não sei se convém ficar em Brasília e aqui, dividindo o tempo e perdendo-se em viagens que serão, por sua vez, de financiamento difícil. A PUC-SP serve para quebrar um galho. Mais que isso, seria preciso fazer como o Octavio Ianni e dar duro mesmo.

Falei pelo telefone com a Carolina. Sobre o livro saído da pesquisa nada posso fazer. Endossei sua competência, mas isso é dispensável. Não tenho meio direto de influência sobre outras coleções da editora. Quanto ao Basil Bernstein, tomei a decisão de incluí-lo na área de ciências sociais (sociologia). Assim, as delongas sobre a criação da nova coleção não interferirão sobre o seu trabalho. A Carolina deve entender-se com você a respeito.

Por enquanto é tudo. Lamento ser um homem desvalido deliberadamente desvalido -, pois me desinstitucionalizei voluntariamente. Os estudantes custaram a compreender $\mathrm{e}$ parece que não se conformam com isso; eu poderia render muitos pontos nas carreiras acadêmicas dos meus estudantes. Contudo, repudiei essa via, para não voltar a ela sob qualquer circunstância. Mas, preciso ter muita força de vontade para resistir e, uma vez ou outra, capitulo, endossando uma ou outra coisa, excepcionalmente - não como a exceção que confirma a regra -, porém com o sangue escorrendo do coração. Acho que vocês me compreendem e, se não aprovam, pelo menos não me condenam. Há rupturas e rupturas. A minha levou ao fundo do poço, onde fiquei isolado e sem os riscos de ser salvo por uma caravana de mercadores. A cisterna é boa e posso movimentarme e sem os constrangimentos e as violações do encurralamento institucional. Voltei à condição de lumpen, de vagabundo, embora tenha mais dinheiro que em qualquer outra época de minha vida. Ele entra e sai porque, ainda aqui, o liame com a vida institucionalizada é representado pela Myrian. 
Muitos acham que desprezo a universidade e o trabalho acadêmico. Que inversão! O que desprezo é a universidade voltada sobre si mesma e o trabalho acadêmico que não tem outro fim que o da "carreira", do "êxito profissional" e da "produção" para o currículo.

1964 mostrou-me que a universidade que eu tinha na cabeça nunca existirá no Brasil e que o verdadeiro campo de batalha só existe quando $o$ intelectual pode mergulhar em movimentos que arrasam para construir, o que ainda é uma miragem em nossa pobre cena política, que mais se parece com um teatro de marionetes. Por conseguinte, luto como posso, na certeza que os tais movimentos virão - na verdade, se há alguma esperança, desde 1978, ela vem daí - embora seja difícil que eu próprio venha a aproveitar essa revirada liberadora da história.

Essa saudação é um pouco dura. Não the mostro um buquê de flores, como sinal de boas vindas. Mas quem disse que eu poderia pensar que você precisa disso? Com um abraço muito cordial para você e o Sérgio,

Florestan

Barbara:

Você deve andar pesarosa comigo. Parece que morri. É que, de fato, entrei em uma fase da minha vida na qual perdi o controle. do meu tempo e da minha vontade. Luto para ser eu mesmo e $o$ sou, mas recusando-me aos meus entes mais queridos.

Desejo a você e ao Sérgio um 1990 rico de novas perspectivas.

Com o carinho de sempre,

Florestan 
Recebi sua carta, que me causou enorme alegria, e o convite para colaborar no livro projetado. Não posso dar resposta por este semestre. A vida virou um caldeirão, um lutar em torno da questão de revisão, no interior do PT e na campanha de luta, e a pesada rotina para um homem de quase 74 anos e com doença incurável.

Depois de muito refletir, lancei o seu projeto para o que farei depois do fim do atual mandato. Houve protestos dos meus apoiadores - que chegaram a aventar a necessidade de uma Assembléia para discutir se eu podia recusar um terceiro mandato. Estavam preparados para isso desde o término de $1992 . .$. Mas penso que um partido socialista deve restringir o número de mandatos a dois, para evitar a "profissionalização política", com suas conseqüências nefastas. Além disso, não posso prometer nada que não possa cumprir!

Espero que você e o Sérgio estejam aproveitando a estadia na Alemanha. Não consegui visitá-los aqui: idas e vindas malucas para São Paulo todas as semanas. Privado desse prazer, fico contente com seu retorno a lides intelectuais fora do Brasil e em lugares que também são de sua intimidade.

Envio-lhes os cumprimentos mais cordiais e, a você, o carinho especial que merece,

Florestan

Cara Barbara:

Estou em falta com você. Mas este ano tive duas internações hospitalares, sendo uma de mais de um mês. Sofri uma operação e abandonei a idéia de disputar outro mandato. Os grupos que me apóiam em São Paulo, acima de distinções partidárias, quiseram colocar a minha decisão em debate e voto por uma assembléia. Desta vez teria a maior votação; o meu trabalho 
silencioso rendeu mais que a publicidade pelos meios de comunicação... Fui inabalável, porém. Com uma dưra doença crônica, mais de 74 anos e a idéia de que um socialista não deve concorrer mais que duas vezes ao Legislativo, correndo o risco de profissionalizar-se, dispunha de razões de sobra para só aproveitar a experiência...

Já antes ficara aflito. Não podia aceitar o convite no tema que me foi proposto, mas deixei correr marfim, certo de algum encontro.

Acontece que já fora, antes, convidado por amigo íntimo para um colóquio sobre educação e me fora proposto o mesmo tema, com 1.000 dólares de pagamento. Recusei, porque hoje não estou mais nas décadas de 50 e 60 . Precisaria enfrentar uma análise cansativa, que não tenho como enfrentar, para me pôr a corrente de dados, análises, comparações que antes fazia com os pés nas costas.

Ainda ando em convalescença e o PT já torrou sua paciência com as minhas faltas por doença - embora sempre tenha dado conta do meu trabalho. Agora, é impraticável lançar-me numa aventura que a aborreceria. Um tema mais ameno é o que espero, para não the dizer não. E o tempo é um fantasma que me cerca permanentemente. Por feio que the pareça, peço-lhe clemência e algo que possa desempenhar sem muito esforço.

Cordialmente,

Florestan Fernandes 